\title{
Management of growth failure in Crohn's disease
}

\author{
J A Walker-Smith
}

Crohn's disease is one of the chronic inflammatory bowel diseases which at present is still of unknown cause. It has been known for some time that this disorder may lead to significant impairment of linear growth ${ }^{1}$ and delay in the onset of puberty. Indeed Crohn's disease in childhood may present as short stature or delay in pubertal maturation without any gastrointestinal symptoms. There may be irreversible consequences in terms of reduced potential for height unless this diagnosis is made promptly and treatment instituted to induce remission of disease activity, thus permitting restoration of normal growth. ${ }^{2}$ A full blood count, erythrocyte sedimentation rate, and $C$ reactive protein estimation should be standard screening tests for short stature. ${ }^{3}$

In this paper I shall give an account of my own personal practice in the management of children with Crohn's disease and chronic inflammatory bowel disease in the paediatric inflammatory bowel disease clinic which was first established at St Bartholomew's Hospital in 1978 and transferred to the Royal Free Hospital in 1995.

\section{Definitions of growth failure}

Growth failure may be defined in various ways: (1) by a static measurement of height below the third centile; (2) by evidence of significant growth faltering as assessed over a period of time by centile chart analysis (that is, a shift from higher to lower centiles of height attained); (3) by showing a reduction in height velocity, which is the most accurate measurement of growth. Measurement of height velocity requires accurate measurement of height over a number of months (a minimum of three months). It may be defined as: (1) height velocity of less than the third centile by centile chart analysis ${ }^{4}$; (2) height velocity $<-2.0$ SDS (standard deviation score). ${ }^{2}$

For research comparisons, standard deviation scores or $\mathrm{Z}$ scores are useful for defining changes in height percentile or in height velocity, ${ }^{5}$ but for routine clinical management centile chart analysis is both practical and adequate.

Department o

Paediatric

Gastroenterology, The

Royal Free Hospital,

Pond Street,

Hampstead, London

NW3 20G

Correspondence to:

Professor Walker-Smith. A survey of 96 children attending the paediatric inflammatory bowel disease clinic showed that $23 \%$ had heights below the third centile but $36 \%$ had height velocity below the third centile. ${ }^{4}$ The American experience is similar. ${ }^{5}$
This is chiefly a problem of the adolescent and preadolescent years. The height of most younger children with Crohn's disease is normal.

\section{Long term outcome of growth failure}

There are three published studies of children with chronic inflammatory bowel disease from prepuberty or early puberty through puberty until cessation of growth. ${ }^{2} 57$ While most patients achieved a final height between the fifth and the 97th centile the distribution was skewed towards the lower centiles, and in some children with Crohn's disease a significant reduction of final height was found. A single observation of 60 adults with so called juvenile onset of chronic inflammatory bowel disease showed that only three had impaired adult growth stature. ${ }^{8}$ However, 18 female patients had experienced menarche before the diagnosis of chronic inflammatory bowel disease. No pubertal staging of male patients was reported. The impact of disease on growth would be expected to be less in those patients whose disease preceded their peak growth velocity. As it is known that growth velocity is reduced in children with prepubertal onset of inflammatory bowel disease, ${ }^{2}$ it is difficult to compare outcome in such clinical series when populations are not at similar risk. ${ }^{9}$

Clearly advances in modern treatment of chronic inflammatory bowel disease, both medical and surgical, are likely to have a beneficial outcome upon final height. ${ }^{9} 10$

\section{Pubertal delay and growth failure}

Striking pubertal delay may occur in patients in whom a remission has never been successfully induced or in whom relapses have been frequent. ${ }^{4}$ In the absence of a remission of disease activity the age of onset of puberty may be delayed indefinitely.

When the age of onset of puberty was taken as breast stage 2 (B2) in girls and testicular volume of $4 \mathrm{ml}$ (TV4) in boys, a significant delay in onset of puberty was found in adolescents with chronic inflammatory bowel disease (fig 1 ).

Precise pubertal staging (1-5) using the Tanner classification is important, and involves accurate measurement of testicular volume in boys using an orchidometer. Height increase during puberty may be impaired in these children. ${ }^{4}$

There is a paradoxical effect in relation to children with similar prepubertal heights late 

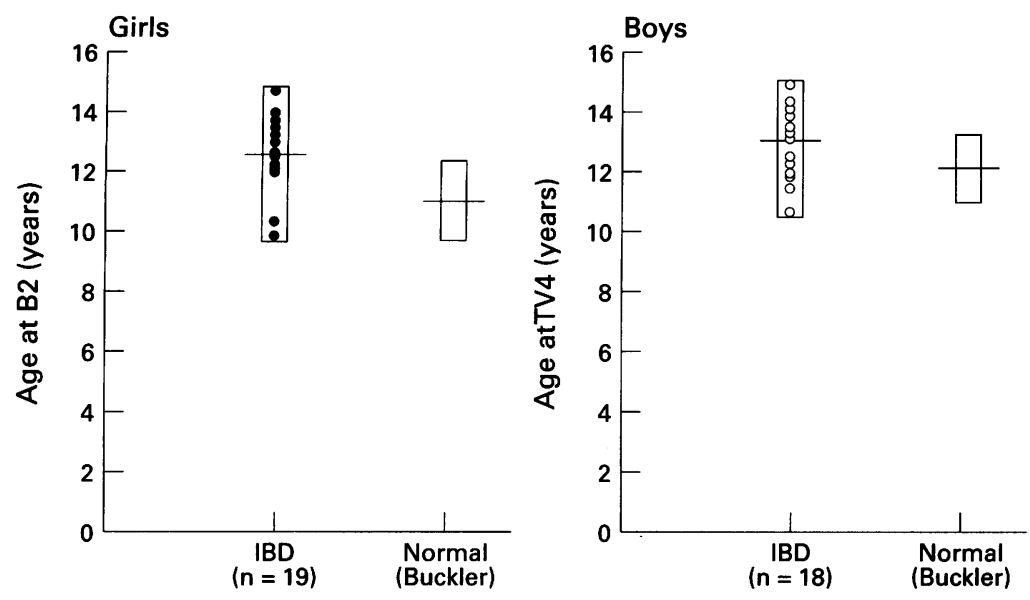

Figure 1 Age of onset of puberty in girls (B2) and boys (TV4) with chronic inflammatory bowel disease. ${ }^{4}$

puberty leads on average to a larger final height than does early puberty. ${ }^{11}$ So in children with delayed puberty, if there is eventually a normal pubertal growth spurt this may compensate for a period of poor growth occurring earlier in life. ${ }^{2}$ However, in children in whom there is a relapse during the pubertal growth process itself, there may be no real growth spurt, with as little as $1-2 \mathrm{~cm}$ of height being acquired during Tanner stages $2-4{ }^{4}$

Such pubertal delay may cause considerable personal distress to these children and their parents and may be a source of much unhappiness in the school environment. An appropriately timed therapeutic intervention by the clinician which can relieve this problem is vital, for example surgical resection of inflamed intestine can lead to onset of puberty within a year. ${ }^{4}$ Individual counselling and psychotherapy is important here ${ }^{12}$ but a caring sympathetic team of doctors and nurses who have time to recognise and discuss these problems with the children and their parents goes a long way. Once a remission of disease activity is achieved, delayed puberty may not inevitably be associated with reduced final height.

\section{Pathogenesis of growth failure}

The suppression of linear growth that occurs in children with active Crohn's disease has been attributed chiefly to malnutrition. It has indeed been shown that restoration of nutrition, either by the enteral or the parenteral route, may restore normal growth in these children. ${ }^{13}$ However, there is evidence that the inflammatory process per se may itself be a major factor in leading to growth retardation. This evidence includes the observation that products of the activated macrophage such as tumour necrosis factor- $\alpha$ (TNF- $\alpha)$ may be increased in the serum of children with active Crohn's disease. ${ }^{14}$ This increase may synergise with other products of activated macrophages, for example interleukin-1 which may also be raised in Crohn's disease. ${ }^{15}$ Excess production of TNF- $\alpha$ alone, however, caused growth failure and wasting in TNF- $\alpha$ transgenic mice. This could be prevented by an anti-TNF- $\alpha$ monoclonal antibody. ${ }^{16}$ Chronic elevation of serum TNF- $\alpha$ or interleukin-2 (IL-2) may have direct inhibitory effects upon new bone formation at the epiphyseal plate. ${ }^{17}{ }^{18}$ As it is now clear that chronic $\mathrm{T}$ cell activation, characterised by production of $T$ helper 1 cytokines (IL-2, $\gamma$-interferon) associated with macrophage activation is the central immunological event in Crohn's disease, any treatment that can down regulate this process will have a beneficial impact on growth retardation.

\section{Monitoring of growth}

Accurate measurement of height and plotting on a centile chart, together with calculation of growth velocity, are central to management. ${ }^{19}$ A fall in height velocity may be the earliest manifestation of Crohn's disease. Likewise a subsequent fall of height velocity after a period of successful management may indicate relapse before overt gastrointestinal symptoms occur. The careful documentation of accurate pubertal staging, for example the accurate recording of testicular volumes as discussed above, is also of key importance. Arrest of pubertal development may represent early relapse. It is urgent in these circumstances to induce remission of disease. Radiological determination of bone age may be very helpful in growth monitoring and indicate the prognosis for growth. When there is significant delayed bone age this carries a good prognosis for growth potential.

Close partnership between paediatric gastroenterologist and paediatric endocrinologist is particularly valuable. Joint clinics every four months for children with growth failure and inflammatory bowel have been held in my hospital since 1985. These have been invaluable and educational.

\section{Management of growth failure}

In my own practice, enteral nutrition is now the first line treatment for all children with Crohn's disease, both for small and large intestinal disease, although the evidence for success is better for small intestinal disease. ${ }^{20}{ }^{21}$ Enteral nutrition may be effective both by restoring nutrition when impaired or inducing a remission of disease activity.

When remission is induced by such a strategy, it carries an excellent prognosis for growth. Some years ago we showed in children that enteral nutrition was as effective as steroids in inducing a remission in Crohn's disease of the small intestine. ${ }^{20}$ When effective, enteral nutrition carries a better outlook than steroids for growth retardation and avoids the risk of growth impairment from steroids per se. Continued use of nasogastric supplements before completion of puberty has been associated with improved linear growth. ${ }^{22}$

Enteral nutrition may induce a remission by reducing mucosal cytokine production in some at present unknown manner. ${ }^{23}{ }^{24}$ Both whole protein, that is polymeric, ${ }^{21}$ and protein hydrolysate feeds, that is semielemental, ${ }^{20}$ have been shown to be effective in inducing a remission.

Growth hormone deficiency is not a significant factor in most cases. Normal growth hormone secretion has been shown in growth retarded children with Crohn's disease who were not treated with steroids, ${ }^{25}$ although low 
Table 1 Effect of surgery on growth velocity in 40 children grouped according to disease location at time of primary operation

\begin{tabular}{|c|c|c|c|c|c|c|c|}
\hline \multirow[b]{2}{*}{$\begin{array}{l}\text { Site of } \\
\text { disease }\end{array}$} & \multirow[b]{2}{*}{$\begin{array}{l}\text { No of } \\
\text { patients }\end{array}$} & \multirow{2}{*}{$\begin{array}{l}\text { No } \\
<3 r d \\
\text { centile }\end{array}$} & \multirow{2}{*}{$\begin{array}{l}\text { Mean } \\
\text { age at } \\
\text { surgery } \\
\text { (years) }\end{array}$} & \multicolumn{2}{|c|}{ Growth velocity ${ }^{*}$} & \multirow{2}{*}{$\begin{array}{l}\text { Percentage } \\
\text { with increase } \\
\text { in growth } \\
\text { velocity }\end{array}$} & \multirow{2}{*}{$\begin{array}{l}\text { Percentage } \\
\text { with }>\text { twofold } \\
\text { increase in } \\
\text { growth } \\
\text { velocity }\end{array}$} \\
\hline & & & & $\begin{array}{l}\text { Before } \\
\text { surgery } \\
\text { (cm/year) }\end{array}$ & $\begin{array}{l}\text { After } \\
\text { surgery } \\
\text { (cm/year) }\end{array}$ & & \\
\hline $\begin{array}{l}\text { Small } \\
\text { bowel }\end{array}$ & 6 & 2 & 14.5 & 2.77 & 7.28 & 83 & 67 \\
\hline Ileocaecal & 20 & 9 & 14.3 & 2.72 & 6.92 & 88 & 65 \\
\hline Colonic & 14 & 7 & 13.4 & 1.92 & 7.44 & 92 & 77 \\
\hline Total & 40 & 18 & 14.0 & 2.45 & 7.18 & 89 & 69 \\
\hline
\end{tabular}

* Growth velocity has been calculated for a minimum of 12 months before and after surgery ${ }^{28}$.

urinary growth hormone secretion was found in patients on steroids. It is well known that steroids may blunt the growth hormone response.

Although thyroid function is typically normal in children with Crohn's disease, there may be a reduced conversion of T4 to T3 leading to reduced T3 levels. ${ }^{26}$ These return promptly to normal on induction of remission.

In boys when there is extreme delay of puberty, that is, testicular volume below $10 \mathrm{ml}$, monthly intramuscular injections for 3-6 months of testosterone enanthate $125 \mathrm{mg}$ may be helpful, especially when there is clinical remission of disease (Savage MO, personal communication). However, all medical treatment (enteral nutrition and drug therapy) may fail due to either (1) inability to induce or sustain an adequate disease remission, or (2) dependency on a dose of steroids which itself may impair growth, even when steroid sparing treatment with azathioprine has been used. Surgery may then offer a dramatic opportunity to produce a long standing remission and so restore growth, with the possibility of allowing catch up growth and a normal pubertal growth spurt when correctly timed ${ }^{1027}$ (table 1 ; fig 2).

Thus surgery for growth retardation is indicated when there is failure of other treatment to induce an adequate remission. This surgical option is only possible when the disease is not too extensive and it is feasible to resect bowel ${ }^{27}$ (table 2).

Right hemicolectomy, limited small bowel resection, stricturoplasty, and subtotal colectomy with ileostomy are all options, depending on individual circumstances. ${ }^{28}$

When all gross disease can be resected, this has the best prognosis. It is vital to have up to date knowledge of the extent and severity of the disease at the time when surgery is contemplated. ${ }^{29}$ This can only be acquired by colonoscopy with ileoscopy and barium follow through studies. Sometimes upper endoscopy, ultrasound, and abdominal computerised axial tomography scans are also required.

Surgical treatment performed up to the early stages of puberty may be dramatically helpful but if delayed until after puberty is well established, the opportunity for growth restoration may be very limited or it may not be possible to achieve it at all (table 2).

Whatever strategy is used to produce a remission, its completeness and duration through puberty is a key factor in influencing growth potential. $^{30}$

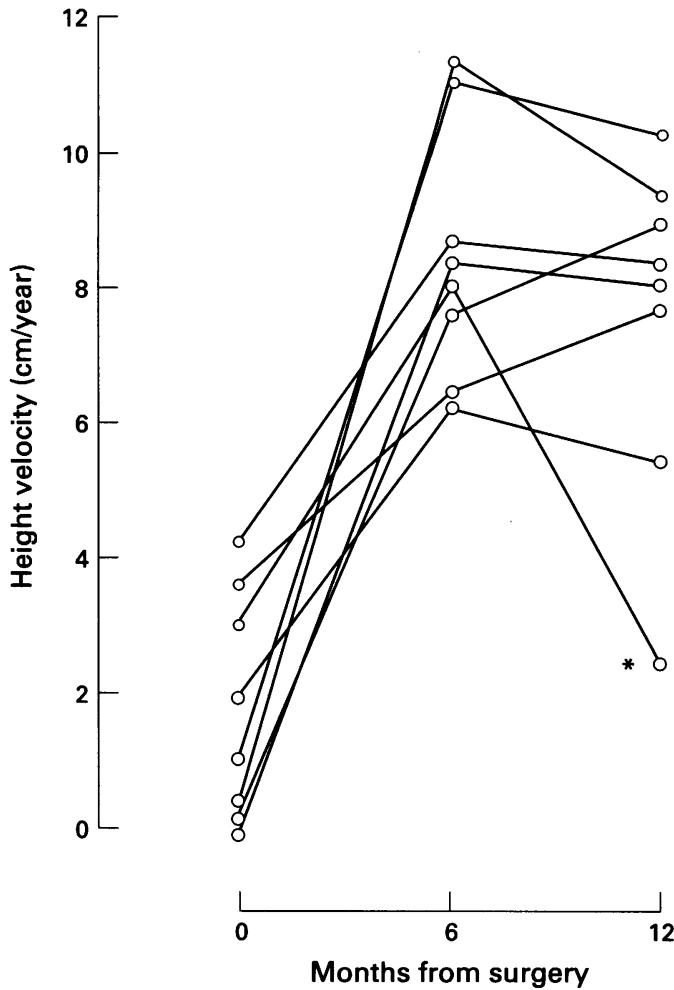

Figure 2 Height velocity before and after surgery.

Table 2 Mean annual height velocities (cm/year) before and after surgery for Crohn's disease in 42 children grouped according to pubertal stage

\begin{tabular}{|c|c|c|c|c|c|c|}
\hline & \multicolumn{2}{|c|}{ Stage $1(n=18)$} & \multicolumn{2}{|c|}{$\begin{array}{l}\text { Stage } 2+3 \\
(n=14)\end{array}$} & \multicolumn{2}{|c|}{$\begin{array}{l}\text { Stage } 4+5 \\
(n=10)\end{array}$} \\
\hline & Pre & Post & Pre & Post & Pre & Post \\
\hline $\begin{array}{l}\text { Male } \\
\text { Female }\end{array}$ & $\begin{array}{l}1.85 \\
1.64\end{array}$ & $\begin{array}{l}7.40 \\
9.08\end{array}$ & $\begin{array}{l}2.81 \\
2.23\end{array}$ & $\begin{array}{l}8.20 \\
7.14\end{array}$ & $\begin{array}{l}3.32 \\
2.87\end{array}$ & $\begin{array}{l}4.50 \\
3.09\end{array}$ \\
\hline
\end{tabular}

\section{Conclusion}

Increasing awareness of the importance of slowing of growth and development, both as a mode of presentation of Crohn's disease in children and as a complication of established disease, should allow greater accuracy in the early diagnosis of Crohn's disease and in the early recognition of relapse, and enable the most appropriate treatment to be given. When timed appropriately, modern treatments offer the opportunity for children to achieve their full growth potential despite having Crohn's disease. There is a window of therapeutic opportunity which must be taken advantage of before puberty is complete.

I wish to thank Dr M O Savage who has been my colleague in the joint growth inflammatory bowel disease clinic from 1985 to the present and to the Crohn's in Childhood Research Association (CICRA) which has supported so much of the clinical research upon which my present clinical practice is based.

1 Silverman FN. Regional enteritis in children. Aust Paediatr $\mathfrak{f}$ 1966;2:20-4.

2 Hildebrand $\mathrm{H}$, Karlberg J, Kristiansson B. Longitudinal growth in children and adolescents with inflammator bowel disease. $\mathcal{F}$ Pediatr Gastroenterol Nutr 1994;18:165-73.

3 Beattie RM, Walker-Smith JA, Murch SH. Indications for investigation of chronic gastrointestinal symptoms. Arch Dis Child 1995;73:354-5.

4 Brain CE, Savage MO. Growth and puberty in chronic inflammatory bowel disease. Bailliere's Clin Gastroenterol 1994;8:83-101.

5 Kirschner BS. Growth and development in chronic inflammatory bowel disease. Acta Paediatr Scand Suppl 1990;366: 98-104. 
6 Evans $M$, Walker-Smith JA. Recording growth and development in children with inflammatory bowel disease. $B M \mathcal{F}$ 1989;298:1312-3.

7 Markowitz J, Grancher K, Rosa J, Aiges H, Daum F. Growth failure in pediatric inflammatory bowel disease. $\mathcal{f}$ Pediat Gastroenterol Nutr 1993;16:373-80.

8 Ferguson A, Sedgewick DM. Juvenile onset inflammatory bowel disease: height and body mass index in adult life. BMF 1994;308:1259-63.

9 Kirschner BS. Maintenance therapy in inflammatory bowel disease: effects on growth and relapse rate. Inflamm Bowel Dis $1995 ; 1: 321-3$

10 Lipson AB, Savage MO, Davies PSW. Acceleration of linear growth following intestinal resection for Crohn's disease. Eur $\mathcal{F}$ Pediatr 1990;149:687-90.

11 Karlberg J, Fryer JG, Engstrom I, Karlberg P. Analysis of linear growth using a mathematical model. II. From 3 to 21 years of age. Acta Paediatr Scand 1987;337(suppl):12-29

12 Bruce T. Emotional sequelae of chronic inflammatory bowel disease in children and adolescents. Clin Gastroenterol 1986;15:89-105

13 Kelts DG, Grand RJ, Shen G, Watkins JB, Werlin SL, Boehme C. Nutritional basis of growth failure in children and adolescents with Crohn's disease. Gastroenterology 1979;76: $720-7$

14 Murch SH, Lamkin VA, Savage MO, Walker-Smith JA, MacDonald TT. Serum concentrations of tumour necrosis factor a in children chronic inflammatory bowel disease. Gut 1991;32:913-7.

15 Satsangi J, Walstencroft JC, Cason J. Interleukin-1 in Crohn's disease. Clin Exp Immunol 1987;67:594-605.

16 Siegel SA, Sheahy DJ, Nakada MT. The mouse human chimeric monoclonal antibody CA2 neutralizes TNF in-vitro meric monoclonal antibody CA2 neutralizes TNF in-vitro and protects transgenic mice from cach

17 Murch SH. Inflammatory mediators and suppression of growth in paediatric chronic IBD. In: Tytgat GNJ, Bartelsman JF, Deventer SJH, eds. Inflammatory bowel diseases, Falk Symposium 85, 1995;71:598-603.

18 Mundy GR. Effects of TNF on bone and cartilage. In: Beutler $\mathrm{B}$, ed. Tumor necrosis factors: the molecules and their emerging role in medicine. New York: Raven Press, 1992:107-16.
19 Walker-Smith JA, Savage MO. Effects of inflammatory bowel disease on growth. Growth Matters 1993;12:10-12.

20 Sanderson IR, Udeen S, Davies PSW, Savage MO, WalkerSmith JA. Remission induced by an elemental diet in small bowel Crohn's disease. Arch Dis Child 1987;61:123-7.

21 Beattie RM, Schiffrin EJS, Donnet-Hughes A, et al. Polymeric nutrition as the primary therapy in children with small bowel Crohn's disase. Alimentary Pharmacol Ther 1994;8:609-15.

22 Wilschanski $M$, Sherman $P$, Pencharaz $P$, Davis L, Corey MA, Griffiths A. Supplementary enteral nutrition maintains remission in paediatric Crohn's disease. Gut 1996;38: 543-8.

23 Breeze EJ, Michie CA, Nicholls SW, et al. Tumor necrosis factor-alpha producing cells in the intestinal mucosa of children with inflammatory bowel disease. Gastroenterology 1994;106:1455-66.

24 Breeze EJ, Michie CA, Nicholls SW, et al. The effect of treatment on lymphokine-secreting cells in the intestinal mucosa of children with Crohn's disease. Alimentary Pharmacol Ther 1995;9:547-53

25 Braegger CP, Torresani T, Murch SH, Savage MO, WalkerSmith JA, MacDonald TT. Urinary growth hormone in rowth-impaired children with chronic inflammatory bowel disease. F Pediatr Gastroenterol Nutr 1993;16:49-52.

26 Chong SKF, Grossman A, Walker-Smith JA, Rees LH. Endocrine dysfunction in children with Crohn's disease. $\mathcal{f}$ Pediatr Gastroenterol Nutr 1984;3:529-35.

27 Davies G, Evans CM, Shand WS, Walker-Smith JA. Surgery for Crohn's disease in childhood: influence of site of disease and operative procedure on outcome. Br f Surg 1990;77: $891-4$.

28 Shand WS. Surgical therapy of chronic inflammatory bowel disease in childhood. Balliere's Clin Gastroenterol 1994;8: 149-81.

29 Walker-Smith JA. Clinical and diagnostic features of Crohn's disease and ulcerative colitis in childhood. Crohn's disease and ulcerative colitis

30 Walker-Smith JA. Progress in understanding paediatric IBD peculiarities. In: Tytgat GNJ, Bartelsman JF, Deventer $\mathrm{SJH}$, eds. Inflammatory bowel diseases. Falk Symposium 85, 1995:329-33. 